\title{
Disgorgement as an Antitrust Remedy
}

\section{Citation}

Einer R. Elhauge, Disgorgement as an Antitrust Remedy, 76 Antitrust L.J. 79 (2009).

\section{Permanent link}

http://nrs.harvard.edu/urn-3:HUL.InstRepos:11222941

\section{Terms of Use}

This article was downloaded from Harvard University's DASH repository, and is made available under the terms and conditions applicable to Open Access Policy Articles, as set forth at http:// nrs.harvard.edu/urn-3:HUL.InstRepos:dash.current.terms-of-use\#OAP

\section{Share Your Story}

The Harvard community has made this article openly available.

Please share how this access benefits you. Submit a story.

Accessibility 


\title{
DISGORGEMENT AS AN ANTITRUST REMEDY
}

\author{
Einer ElHauge*
}

My topic is an antitrust remedy that is legally available, enormously powerful, but seldom used-disgorgement. I want to ask what explains the rare usage of this remedy in antitrust cases and whether the reasons for its historic backstage status continue to apply today to dominant firm misconduct. More provocatively, given the growing obstacles to private and class action damage suits and the frequent ineffectiveness of behavioral and structural remedies for monopolization, is it time for disgorgement to assume center stage as an antitrust remedy? While my comments will focus on U.S. law, I also offer some observations about how disgorgement theory might offer a way to better explain, and cabin, the otherwise puzzling EU claim of excessive pricing.

\section{LEGAL AVAILABILITY AND CONVENTIONAL REASONS FOR RARE USAGE}

One's first reaction might well be that perhaps the rare usage reflects some underlying insecurity about whether disgorgement really is a permissible antitrust remedy. But there is surprisingly little doubt that equitable antitrust remedies include requiring violators to disgorge any illegally obtained profits. In United States $v$. Paramount Pictures, the Court held that injunctions to deprive the defendant of the fruits of its anticompetitive conduct should include injunctions ordering the defendant to divest property

if the property was acquired ... as a result of practices which constitute unreasonable restraints of trade. Otherwise, there would be reward from the conspiracy through retention of its fruits. Hence the problem of the District Court does not end with enjoining continuance of the unlawful restraints nor with dissolving the combination which launched the conspiracy. Its function includes undoing what the con-

* Petrie Professor of Law, Harvard Law School. I am grateful for comments from Richard Brunell, Bert Foer, Deborah Garza, John Harkrider, Bob Lande, Daryl Levinson, Doug Melamed, Bill Rubenstein, and the participants in the ABA Section of Antitrust Law Conference on Remedies for Dominant Firm Misconduct at the University of Virginia.

76 Antitrust Law Journal No. 1 (2009). Copyright 2009 American Bar Association. Reproduced by permission. All rights reserved. This information or any portion thereof may not be copied or disseminated in any form or by any means or downloaded or stored in an electronic database or retrieval system without the express written consent of the American Bar Association. 
spiracy achieved .... [T] he requirement that the defendants restore what they unlawfully obtained is no more punishment than the familiar remedy of restitution. ${ }^{1}$

This language seems broad enough not only to authorize the government to bring antitrust claims seeking the disgorgement of any supracompetitive profits causally related to antitrust violations, but even to require doing so in any case where other remedies do not suffice to deprive a violator of all its illicit fruits. Other Supreme Court cases are equally emphatic. In United States v. United Shoe Machinery Corp., the Court stated: "It is of course established that, in a $\$ 2$ case, upon appropriate findings of violation, it is the duty of the court to prescribe relief which will . . . deny to the defendant the fruits of its statutory violation ...." " And the Court in United States $v$. Grinnell held that "adequate relief in a monopolization case should . . . deprive the defendants of any of the benefits of the illegal conduct ...."”

To be sure, none of these Supreme Court antitrust cases involved the disgorgement of cold hard cash. However, the Federal Trade Commission has sought monetary disgorgement as injunctive relief and had its authority to do so upheld in many cases. ${ }^{4}$ The recent Bush administration Department of Justice took the position that it had the authority to seek disgorgement for antitrust violations, and both the Bush and Clinton Departments of Justice actually obtained disgorgement in contempt actions for violations of consent decrees. ${ }^{5}$ The Areeda treatise concurs that antitrust "equity relief may include . . the disgorgement of improperly obtained gains." ${ }^{6}$ Indeed, the Antitrust Modernization Commission

\footnotetext{
1334 U.S. 131, 171-72 (1948).

2391 U.S. 244, 250 (1968).

3384 U.S. 563, 577 (1966). See also Schine Chain Theatres, Inc. v. United States, 334 U.S. 110, 128-29 (1948) (equitable relief functions include: "It deprives the antitrust defendants of the benefits of their conspiracy."); United States v. Microsoft, 253 F.3d 34, 103 (D.C. Cir. 2001) (en banc) ("[A] remedies decree in an antitrust case must seek to . . 'deny to the defendant the fruits of its statutory violation . . ..'”).

${ }^{4}$ See FTC v. Munoz, 17 Fed. Appx. 624, 626 (9th Cir. 2001); FTC v. Febre, 128 F.3d 530 (7th Cir. 1997); FTC v. Gem Merch. Corp., 87 F.3d 466 (11th Cir. 1996); FTC v. Security Rare Coin \& Bullion Corp., 931 F.2d 1312 (8th Cir. 1991); FTC v. Southwest Sunsites, Inc., 665 F.2d 711 (5th Cir. 1982); FTC v. Ameridebt, Inc., 373 F. Supp. 2d 558 (D. Md. 2005); FTC v. Mylan Labs., 62 F. Supp. 2d 25, 36-37 (D.D.C. 1999).

${ }^{5}$ See Reply Brief for the United States at 4 \& n.3, United States v. Philip Morris USA, Inc., 546 U.S. 690 (2005) (No. 05-92); Press Release, U.S. Dep't of Justice, Court Finds Smith International and Schlumberger Ltd. Guilty of Criminal Contempt for Violating Consent Decree (Dec. 9, 1999), available at http://www.usdoj.gov/atr/public/press_releases/1999/3948.htm; Settlement Agreement and Order at 3, United States v. Cal Drive Int'l. Inc., No. 1:05CV02041 (D.D.C. Nov. 26, 2007).

6 2A Phillip E. Areeda \& Herbert Hovenkamp, Antitrust Law: An Analysis of Antitrust Principles and their Application Il 325a (3d ed. 2006). As the Areeda treatise
} 
concluded that the ability of antitrust agencies to secure disgorgement as a remedy was so well-established that there was no need to clarify it. ${ }^{7}$

Still, while its formal availability is clear, there is also no doubt that disgorgement has, so far, rarely been pursued in antitrust cases. The DOJ apparently has done so only in those two contempt actions. Although the FTC regularly pursues equitable monetary remedies for consumer protection violations, it has done so in only eleven antitrust cases. $^{8}$ The FTC has also issued a policy statement indicating it intends to seek disgorgement only in "exceptional cases." 9 The statement says the FTC will consider three factors before seeking equitable monetary remedies.

One factor is that "there must be a reasonable basis for calculating the amount of a remedial payment." 10 This factor seems obviously necessary-one can hardly bring a claim for disgorgement without calculating the amount to be disgorged. However, it also seems clear this factor can often be met. Indeed, even where this analysis is difficult, it may well be easier to calculate the amount of illicit profits than it is to calculate the amount of harm to each victim. This factor thus often provides an important advantage to disgorgement suits over claims for damages. (By the way, this is why I will focus on equitable claims for disgorgement, rather than on equitable claims for restitution that, like damage suits, generally require ascertaining the harm to the victims.)

The other two factors the FTC names are (1) the clarity of the violation and (2) the extent to which other remedies, such as private actions, would afford an adequate monetary remedy. The policy statement indi-

indicates, in theory, private parties could also seek disgorgement. But that remedy would seem to be unavailable in any case where they could prove damages to themselves, because that would give them an adequate remedy at law. And when they could not prove their damages, it is unclear whether they would receive any disgorged funds, thus lessening their incentive to sue. Perhaps some courts might allow private parties to seek the creation of a disgorgement fund to generally benefit some set of market participants in a case where damages to particular market participants cannot be established. However, pursuing this sort of strategy via individual actions would still be discouraged by the fact that most of the benefits would go to others who are not funding the litigation, and doing so via class actions would still face the common impact obstacles noted below. In any event, I do not know of any private antitrust case where, this has been attempted, so we so far seem to lack any direct antitrust precedent on the issue in either direction.

7 See Antitrust Modernization Comm'n, Report and Recommendations 286-88 (2007) [hereinafter AMC REPORT], available at http://govinfo.library.unt.edu/amc/report_recommendation/amc_final_report.pdf.

8 See id. at 286.

${ }^{9}$ Fed. Trade Comm'n, Policy Statement on Monetary Equitable Remedies in Competition Cases, 68 Fed. Reg. 45,820, 45,821 (Aug. 4, 2003) [hereinafter Policy Statement on Monetary Equitable Remedies].

${ }^{10} \mathrm{Id}$. 
cates an intention to weigh those two factors against each other in a sliding scale sort of analysis.

The FTC's justification for requiring some special degree of clarity is that this ensures the remedy serves a desirable deterrence function. But deterrence concerns also apply to antitrust damages, and the FTC statement offers no justification for why the degree of clarity necessary to recover damages should be lower than that to obtain public disgorgement. If anything, concerns that unclarity might deter desirable conduct should be lower for public disgorgement claims, given that they are untrebled and brought only when financially disinterested government officials believe the suit is meritorious. And although the deterrence of undesirable conduct is certainly most effective when the illegal nature of that conduct is clear in advance, it is also true that, if we have some set of conduct that is more likely than not to be harmful, then deterring it will, on balance, be beneficial.

Moreover, when a monopolist has actually acquired profits through illegal conduct, it is hard to see what principle of justice justifies the monopolist retaining those ill-gotten gains just because the monopolist was not certain how illegal that conduct was in advance. One might add that, as a practical matter, so little is clear-cut about monopolization standards, ${ }^{11}$ that requiring high levels of advance clarity would effectively sideline disgorgement as a remedy for misconduct by a dominant firm. This would be unfortunate because, as we shall see, disgorgement may be a particularly attractive remedy for dominant firm misconduct.

The remaining FTC factor may really drive the analysis, for much of the hostility toward disgorgement seems based on the general view that private treble damages generally provide monetary relief that goes well beyond disgorgement, so that disgorgement is typically unnecessary. ${ }^{12}$ The FTC policy statement is careful not to buy into this general view too much: it stresses that the general view might not apply in some cases, not only when statutes of limitations bar private claims, but also when a large aggregate injury is inflicted on many small buyers whose stakes do not justify suit or when the direct purchasers who have exclusive standing will not sue. ${ }^{13}$ In practice, however, the rareness with which it has pursued disgorgement suggests the FTC has believed that private actions usually do force defendants to disgorge the profits from their viola-

${ }^{11}$ See generally Einer Elhauge, Defining Better Monopolization Standards, 56 Stan. L. Rev. 253 (2003) [hereinafter Defining Better Monopolization Standards].

12 See, e.g., AMC RePort, supra note 7, at 287.

${ }^{13}$ See Policy Statement on Monetary Equitable Remedies, supra note 9, at 45,822. 
tions. The DOJ must have believed it even more, for it has so far never brought an ordinary disgorgement claim in an antitrust case.

\section{DO THE CONVENTIONAL REASONS STILL SUPPORT RARE USAGE?}

The rare usage of disgorgement actions thus seems to have been based mainly on a general premise that private actions already provide adequate monetary relief, so that disgorgement claims would not provide an additional benefit and in fact might generate over-deterrence. But the adequacy of private actions seems increasingly dubious, especially in monopolization cases.

Such monopolization cases are particularly likely to involve direct purchasers who are intermediaries, like dealers, who pass on most if not all of the anticompetitive costs downstream, are reluctant to provoke the ire of the dominant supplier in their market, and may sometimes even get a share of the supracompetitive profits. ${ }^{14}$ Such direct purchasers are often unwilling to sue. ${ }^{15}$ And the indirect purchasers who suffer most of the harm lack federal standing to sue under Illinois Brick, a doctrine that sounded sensible at the time, but increasingly looks like a mistake that has perversely undercut its own goals of encouraging vigorous antitrust enforcement and avoiding duplicative damages. ${ }^{16}$

When suit is possible by consumers who cannot pass on any of the costs further downstream, their stakes are usually too low to make individual lawsuits feasible, especially given the enormous costs of antitrust litigation. It is striking that the FTC policy statement indicates this sort of circumstance is one that supports a disgorgement action. One might have thought the FTC would simply say that we have class actions to address the problem of numerous low-stakes plaintiffs. But it did not, perhaps because the FTC implicitly recognized that the standards for certifying antitrust class actions have become increasingly difficult to meet for even the most meritorious of cases.

Where once courts recognized that, because antitrust cases involve marketwide injuries, they are uniquely suitable for class action treatments, many courts now seem willing to accept arguments that in

\footnotetext{
14 See Elhauge, Defining Better Monopolization Standards, supra note 11, at 288-92.

${ }^{15}$ See William H. Page, Class Certification in the Microsoft Indirect Purchaser Litigation, $1 \mathrm{~J}$. Competition L. \& EcON. 303, 314-15 \& n.69 (2005) (noting that the computer makers who were the largest direct purchasers generally did not sue Microsoft after it was found liable in the government litigation).

${ }^{16}$ See, e.g., AMC Report, supra note 7, at 267 (advocating the repeal of the doctrine established in Illinois Brick Co. v. Illinois, 431 U.S. 720 (1977)).
} 
markets with product differentiation, buyer negotiation, or price discrimination, injuries are individuated in a way that undermines common proof of injury, even when the case involves horizontal price fixing. ${ }^{17}$ Acceptance of this narrow view in the cases is far from uniform. ${ }^{18}$ I myself would say that one can infer that the narrow view reflects neither sound policy nor a tenable reading of the role class actions were meant to have from the fact that the narrow view has logically led its advocates to the Catch-22 conclusion that courts generally should not certify any antitrust class actions because one needs to analyze individual data to determine if there was a common impact. ${ }^{19}$ Indeed, by requiring precise calculations of the but-for price for each class member, the narrow view imposes a higher burden of proof than would be imposed in an individual case, where proof of injury can be uncertain and any reasonable approximation of the amount of damages suffices. ${ }^{20}$ The narrow view also generally fixates on variations that exist in both the actual and but-for worlds, ignoring the fact such variations cancel each other out when ascertaining injury and damages. ${ }^{21}$

But the point for present purposes is not whether the trend toward the narrow view on antitrust class actions is right or wrong. The point is that the reality of this trend supports having our antitrust agencies take up the slack left by the increasing barriers to antitrust class actions by bringing more disgorgement suits. This is particularly so if the real motive for this trend is the belief that financially interested class action attorneys cannot be trusted with important social policy decisions about how best to regulate markets, because that belief naturally suggests that this power should instead be shifted to disinterested government agencies.

\footnotetext{
${ }^{17}$ See Blades v. Monsanto Co., 400 F.3d 562 (8th Cir. 2005); Ian Simmons et al., Without Presumptions: Rigorous Analysis in Class Certification Proceedings, Antitrust, Summer 2007, at 61 (noting and applauding a trend toward denying certification of antitrust class actions).

${ }^{18}$ See, e.g., William H. Page, Introduction: Reexamining the Standards for Certification of Antitrust Class Actions, Antitrust, Summer 2007, at 53, 54 \& n.13 (noting that some cases continue to adhere to the traditional approach to certifying antitrust class actions); Ellen Meriwether, Rigorous Analysis in Certification of Antitrust Class Actions: A Plaintiff's Perspective, Antitrust, Summer 2007, at 55, 59 (arguing that cases adhering to the traditional approach are correct).

${ }^{19}$ See John H. Johnson \& Gregory K. Leonard, Economics and the Rigorous Analysis of Class Certification in Antitrust Cases, 3 J. Competrtion L. \& Econ. 341 (2007). Among other things, this conclusion seems inconsistent with the Supreme Court opinion distinguishing mass tort class actions from antitrust class actions on the ground that "[p]redominance is a test readily met in certain cases alleging consumer or securities fraud or violations of the antitrust laws." Amchem Prods., Inc. v. Windsor, 521 U.S. 591, 625 (1997). Under the narrow view, predominance is never readily met in any antitrust class action.

20 See Einer Elhauge, United States Antitrust Law \& Economics 19-23 (2008).

${ }^{21} I d$. at $29-30$ \& n.114.
} 
But, you may wonder, are not suits by the excluded rivals more than adequate to deter illegal monopolization?22 Generally not. Part of the problem is that it is too easy to cut side deals with rivals through settlements that may satisfy the financial interests of the rivals but fail to fix (or even worsen) the anticompetitive problem. The more fundamental problem is that any rival claim will be limited to the competitive profits the rival could have earned on some share of the market in the but-for world. A monopolist will generally find it profitable to pay such low competitive profits on a smaller market share out of the monopoly profits it gains on its monopoly market share.$^{23}$ Such rival claims are thus unlikely to result in complete disgorgement of illicit gains.

Finally, some unilateral misconduct is not covered by private antitrust actions, either because the firm has single-firm market power but does not quite have monopoly power nor the specific intent to qualify as an attempted monopolist, or the firm is an oligopolist engaged in unilateral conduct that facilitates that oligopoly. In such cases outside the scope of Sherman Act Section 2, the only available claim is under the FTC Act, for which the only remedies are equitable. Thus, without equitable monetary remedies, such misconduct could not be effectively deterred. The need for such FTC enforcement only increases if, as in the recent Rambus case, courts (in my view incorrectly) narrowly interpret Sherman Act Section 2 not to cover some conduct that results in anticompetitive price increases. ${ }^{24}$

\footnotetext{
22 See Page, supra note 15, at 335 (suggesting they were adequate in Microsoft).

${ }^{23}$ One might think the trebling of damages would adjust for this, but there is no reason to think that rival lost profits equal one-third the total anticompetitive cost. Moreover, treble damages in practice provide closer to single damages because antitrust plaintiffs usually cannot recover prejudgment interest, deadweight loss harm, or umbrella effect overcharges. See Elhauge, supra note 20, at 14-15; Robert H. Lande, Five Myths About Antitrust Damages, 40 U.S.F. L. Rev. 651 (2006). Expected damages are even lower than that once adjusted for the odds and costs of detection and successful adjudication.

${ }^{24}$ See Rambus, Inc. v. FTC, 522 F.3d 456 (D.C. Cir. 2008). The court held that deceiving a standard-setting organization into adopting a standard for which a member had undisclosed patents does not violate Sherman Act Section 2 where the causation finding was that, absent the misconduct, the organization would have either adopted alternative technologies or negotiated a lower price. $I d$. at 463-64. The court reasoned that the latter possible effect would not have been "exclusionary" conduct covered by the Act. Id. I express no view on whether the FTC's findings on deception and alternative causation were correct in the particular case because the relevant issue here is the court's conclusion that such findings would not suffice to find liability as matter of law. The problem with the court's legal reasoning is that, if the findings were correct, then the higher prices resulted because the conduct gave the deceiving member an ex post monopoly when it otherwise would have faced ex ante competition to be included in the standard-that is, the higher prices resulted precisely because of the exclusion of competition. In all anticompetitive conduct cases, it is true that, with competition, buyers might either have bought elsewhere or used the competitive alternatives as leverage for lower prices. In a price-fixing cartel case, for example, buyers may have bought from the same sellers they would have
} 
In short, going by the FTC's own statement of the relevant factors, it would seem that those factors now call for increased usage of disgorgement claims, given the increasing inability of private damage claims to deter antitrust misconduct and force wrongdoers to cough up their illicit booty.

\section{WOULD DISGORGEMENT IMPROVE ON OTHER GOVERNMENT REMEDIES?}

One might further wonder whether the whole framing of the issue by the conventional analysis has things backwards. In it, disgorgement remedies are cast as the understudy, to be employed only when private actors are unable to perform their role. But it is not the case that antitrust agencies generally defer when private actions can seek the same remedy. After all, private parties can also generally pursue injunctive relief, and the agencies do not take this as a reason to forgo injunctive claims. To be sure, when monetary claims are at issue, one might fear duplicative recoveries, but as the FTC policy statement noted, courts have developed various offsets to avoid such duplication. ${ }^{25}$ If the public disgorgement claim succeeds before private actions are terminated, the proceeds can simply be held in escrow in cases where there is a serious concern that the combination may result in monetary payments that exceed treble the total harm the conduct inflicted.

Rather than focusing on whether disgorgement would add something useful to private damage remedies, perhaps the agencies should focus on whether disgorgement would add something useful to the current set of regulatory equitable remedies that the government normally uses.

Consider the fact that, under the recent Bush Administration, the DOJ failed to bring a single monopolization case challenging unilateral or vertical conduct in its eight years. ${ }^{26}$ Now, there are many possible explanations for bringing zero monopolization cases, and from the perspective of an outsider without access to the files, it is hard to be sure which explanation is right. Perhaps the last eight years witnessed a re-

\footnotetext{
bought from without the cartel, just at a higher price. The mistaken logic of the D.C. Circuit would suggest that, absent proof that a cartel changes who buyers purchase from, the cartel does not "harm the competitive process." Id. at 463 (stressing that this is the test of what conduct counts as "exclusionary"). The Court's reliance on NYNEX v. Discon was quite mistaken, for there the deception was alleged to directly raise prices by fraud without any creation of market power. 525 U.S. 128 (1998). Here, in contrast, the deception was found to have created a monopoly power that otherwise would not have existed, and it is that monopoly power that was used to raise prices.

${ }^{25}$ See Policy Statement on Monetary Equitable Remedies, supra note 9, at 45,823 \& n.16.

${ }^{26}$ I exclude a couple of cases involving horizontal combinations where a Section 2 claim was made but added nothing substantive to the other antitrust claims.
} 
markable degree of law-abiding behavior by monopolists. Perhaps the DOJ has wrongly accepted the single monopoly profit theory, notwithstanding all the economic work disproving this theory. ${ }^{27}$ But I think the most defensible rationale for the recent lack of enforcement has to do with a widespread view that, even if the agencies could have won a monopolization case, the structural or behavioral remedies they could have obtained would generally have been unwise or ineffective.

United States v. Microsoft is often offered as Exhibit A for this view. ${ }^{28}$ The case resulted in a unanimous judgment affirming liability by a panel of D.C. Circuit judges that included some of the smartest and most conservative antitrust minds around. And yet the victory was hollow, for ultimately the remedy had no significant effect.

Structural remedies in Microsoft seemed unwise to many because they could have created inefficiencies that harmed consumers rather than benefited them. Breaking up the operating system would have deprived the market of the beneficial network externalities created by a common system, and many thought that the government's requested remedy of separating the operating system from the applications would have lost desirable synergies from their combination..$^{29}$ Nor could one quite say that those structural remedies satisfied the traditional standard of being necessary to undo the anticompetitive effects and ill-gotten gains, ${ }^{30}$ for even without the anticompetitive conduct, Microsoft likely would have had some sort of monopoly share in operating systems and leading shares in many applications, so these remedies would likely have given Microsoft lower market shares than it would have enjoyed without its conduct.

So ultimately the chosen remedies were behavioral. Now, in my view, the behavioral remedies settled for were far weaker than necessary, and

\footnotetext{
${ }^{27}$ See Einer Elhauge, Tying, Bundled Discounts, and the Death of the Single Monopoly Profit Theory, 123 Harv. L. Rev. (forthcoming Dec. 2009) (Harvard Olin Center Working Paper 629, 2009), available at http://ssrn.com/abstract=1345239 (summarizing literature on why the single monopoly profit theory does not apply to tying or bundled discounts absent certain very limited conditions); Elhauge, Defining Better Monopolization Standards, supra note 11, at 282-92 (explaining why the single monopoly profit theory does not apply to other exclusionary conduct because buyers have incentives to agree to the extent some of the anticompetitive effect is externalized onto other buyers either in the same market or further downstream).

28 See United States v. Microsoft Corp., 253 F.3d 34 (D.C. Cir. 2001) (en banc).

${ }^{29}$ See, e.g., John E. Lopatka \& William H. Page, Devising a Microsoft Remedy that Serves Consumers, 9 Geo. Mason L. Rev. 691, 709-11 (2001); Howard A. Shelanski \& J. Gregory Sidak, Antitrust Divestiture in Network Industries, 68 U. CHI. L. Rev. 1, 77-90 (2001).

${ }^{30}$ See ElHauge, supra note 20, at 25.
} 
thus predictably ineffectual from the start. ${ }^{31}$ But the fact is that even the best-designed behavioral remedies have difficulty really changing the operation of markets, create perverse incentives, and are hard to administer, which is why the U.S. agencies generally favor structural remedies over behavioral ones. ${ }^{32}$ Behavioral remedies are even less likely to achieve the goal of depriving the violator of the fruits of its violation.

Moreover, as stressed by the D.C. Circuit, there was a generic problem with applying injunctive remedies to antitrust violations in innovation industries. By the time the typically lengthy antitrust litigation is done, the problem will often have changed, so that agencies are often put in the position of trying to remedy a problem that once was real, but now has become mooted and perhaps replaced by a new one. ${ }^{33}$

Nor are these problems unique to Microsoft. In monopolization cases, structural remedies often create problems because not all of the defendant's monopoly power was caused by its anticompetitive conduct. Structural remedies thus often cannot legally be obtained because they would be overbroad, and even if they could, they frequently can achieve the goal of denying the defendant the fruits of its violation only at the expense of creating inefficiencies that harm consumers. ${ }^{34}$ Behavioral remedies are generally problematic and difficult to enforce ${ }^{35}$ and, even when otherwise effective, do not deprive the defendant of past ill-gotten gains. High-tech industries probably pose the greatest monopolization concerns because of the relative ease with which monopoly power can be acquired and abused, and yet also involve the sort of innovative pace that makes it hard for antitrust injunctions to keep up. ${ }^{36}$ Even outside of the high-tech world, firms are most motivated to engage in exclusionary conduct when their monopoly power is waning and they want to slow down its erosion. ${ }^{37}$ Thus, it will often be the case that, by the time the case is resolved, their monopoly power will have waned enough to moot

\footnotetext{
31 See Einer Elhauge, Soft on Microsoft, Weekly Standard, Mar. 25, 2002, at 17.

32 See U.S. Dep't of Justice, Antitrust Division Policy Guide to Merger Remedies 7-9 (2004), available at http://www.usdoj.gov/atr/public/guidelines/205108.pdf.

33 See Microsoft, 253 F.3d at 48-49.

${ }^{34}$ See Lopatka \& Page, supra note 29, at 707 (noting that divestiture can rarely be obtained as a remedy for exclusionary conduct by a monopolist).

35 See Richard A. Posner, Antitrust Law 273 (2d ed. 2001) (calling “'regulatory decrees' . . . a confession of failure to restore competitive conditions and a sign that the case was probably ill conceived").

${ }^{36}$ See Shelanski \& Sidak, supra note 29, at 36-38 (collecting literature on the greater anticompetitive concerns in high-tech cases, and arguing they are countered by greater difficulties in defining injunctive remedies).

${ }^{37}$ See Elhauge, Defining Better Monopolization Standards, supra note 11, at 337-38.
} 
structural or behavioral remedies, even if the erosion of their power had been slowed down by anticompetitive conduct.

It is thus not hard to imagine a sensible DOJ official concluding after the termination of the Microsoft case that it simply might not be worth bringing similar monopolization claims, no matter how meritorious, because they require a large expenditure of resources, and, even if the government wins, it loses, in the sense that it has no useful remedy to obtain. If you do not think you have any useful remedies available, the number zero starts to make a lot more sense as the number of enforcement actions you would bring.

But all this looks quite different if one takes seriously the option of pursuing disgorgement claims. Even though much of a firm's monopoly share may not be due to its anticompetitive conduct, one can estimate the share that was, and then use economic models to calculate the price and profit effect from the misconduct in question. ${ }^{88}$ Monetizing the degree of illicit gains allows far more fine-grained judgments than structural relief can provide. Moreover, disgorgement does not require a restructuring that may create inefficiencies that would harm consumers. Disgorgement is also much more enforceable than behavioral remedies because it is clear-cut whether the defendant has complied with the order. Finally, disgorgement neatly avoids the problem of antitrust cases being mooted by subsequent industry developments, for however the industry changes, there remains a live issue about whether past profits should be disgorged, and the prospect of such relief will deter anticompetitive conduct. ${ }^{39}$

For all these reasons, disgorgement may be the remedy that offers a potential cure for the recent paralysis of DOJ enforcement in monopolization cases. Lacking any adequate remedy in standard regulatory forms of equitable relief, monetary relief seems more appropriate.

\section{EXCESSIVE PRICING AS A DISGORGEMENT CLAIM}

Disgorgement theory might also be useful on the other side of the Atlantic, helping to provide an answer to the puzzle of what to do with the European Community Treaty provision that condemns excessive

\footnotetext{
${ }^{38}$ See Elhauge, supra note 20, at 22-23.

${ }^{39}$ See Shelanski \& Sidak, supra note 29, at 97-99 (arguing for similar reasons that disgorgement should have been considered as an equitable remedy in the Microsoft case). On the other hand, if the conduct has not yet resulted in ill-gotten gains, then disgorgement will not be an effective remedy, but injunctive remedies ending the misconduct or its structural effects can be.
} 
pricing. ${ }^{40}$ The reason this provision is puzzling is that, on its face, it seems to condemn the possession of dominant market power itself, for any firm with such power could be said to be pricing excessively. Such condemnation would be perverse, given that firms generally enjoy market power because they invested in developing some product or process than offers efficiencies over the alternative market options, for which higher profits are their just reward, a reward we want them to get so as to encourage such efficient investments. ${ }^{41}$ High prices also provide an important market signal that encourages other firms to enter, which would create competition that is more desirable than price regulation and does not raise the same administrative difficulties. Nor does the EC seem to hold the view that all pricing that reflects earned market power is excessive pricing, for if it did, it would routinely bring excessive pricing claims. Indeed, such excessive pricing would seem the far more obvious and easily provable claim to bring against Microsoft, but the EC never pursued it. Instead, excessive pricing claims by the EC seem, if anything, even rarer than U.S. disgorgement claims. ${ }^{42}$

Perhaps the best way to make sense of excessive pricing doctrine is to understand it as something far narrower. To the extent the excessive pricing provision adds something to the EC Treaty's prohibition of price discrimination, ${ }^{43}$ perhaps we should understand it as a claim designed to

${ }^{40}$ Treaty Establishing the European Community (consolidated version), art. 82(a), Dec. 29, 2006, 2006 O.J. (C 321E) 1, 74 (an abuse of a dominant position may consist in "directly or indirectly imposing unfair purchase or selling prices . . ."); Case 27/76, United Brands Co. v. Comm'n, 1978 E.C.R. 207, 215 (holding that this provision makes it illegal for a dominant firm to charge excessive prices).

${ }^{41}$ See Elhauge, Defining Better Monopolization Standards, supra note 11, at 332 (“[W] hen a firm uses proper conduct to create something sufficiently more valuable than existing market options to enjoy dominant market power, then any high prices it earns are the proper social reward for that creation, and the denial of that reward by E.C. law seems ... unsound."); Einer Elhauge, Why Above-Cost Price Cuts to Drive out Entrants Are Not Predatory—and the Implications for Defining Costs and Market Power, 112 YALE L.J. 681, 796 (2003) ("We thus must be careful not to act as if the purpose of antitrust laws were to eliminate monopoly profits themselves. Such profits are an extremely valuable inducement to the creation of better or cheaper products."); Verizon Commc'ns Inc. v. Law Offices of Curtis V. Trinko, LLP, 540 U.S. 398, 407 (2004) ("The mere possession of monopoly power, and the concomitant charging of monopoly prices, is not only not unlawful; it is an important element of the free-market system. The opportunity to charge monopoly prices-at least for a short period-is what attracts 'business acumen' in the first place; it induces risk taking that produces innovation and economic growth.").

42 See Einer Elhauge \& Damien Geradin, Global Antitrust Law \& Economics 254 (2007).

${ }^{43}$ Some cases framed as excessive pricing cases really seem to be cases about price discrimination that is not justified by cost differences, which adds nothing to the separate prohibition of such price discrimination under EU law. See, e.g., Case 27/76, United Brands Co. v. Comm'n, 1978 E.C.R. 207; Treaty Establishing the European Community (consolidated version), art. 82(c), Dec. 29, 2006, 2006 O.J. (C 321E) 1, 74-75. 
deal with the gap that otherwise would be left because EU law prohibits the abuse "of" a dominant position, but does not prohibit anticompetitive conduct that is used to obtain that dominant position in the first place. ${ }^{44}$ In such a case, the anticompetitive conduct that led to the acquisition of dominance cannot itself be called an abuse "of" the dominant position because it preceded the existence of that position. But one could say that any excessive pricing that followed the improper acquisition of dominance was an abuse "of" that dominant position. In contrast, when the dominant position was earned through desirable conduct, then any high prices are a just reward for that conduct. Thus, while an "exercise" of a dominant position, such high pricing should not be considered an "abuse" of it, because the meaning of the word "abuse" is limited to undesirable actions. In short, Article 82 should be interpreted to deem excessive pricing an abuse of a dominant position only when that position was obtained by abusive conduct. ${ }^{45}$ Here, at last, we have a textually plausible interpretation of this provision that would actually make policy sense.

To be sure, the best remedy for a claim that the illicit acquisition of dominance led to excessive pricing might be some sort of structural relief-breaking up the dominant firm to resemble what it would have looked like without the anticompetitive conduct. But another natural remedy for an excessive pricing claim, which might often be more attractive, would be to force the firm to disgorge the price excesses it earned because of the anticompetitive conduct. In short, we could understand excessive pricing claims as a vehicle for a disgorgement remedy.

Such a disgorgement remedy seems especially appropriate in the EU, where the argument is much less plausible that private actions are already adequate to secure disgorgement. This is because, in the EU, unlike the United States, private plaintiffs generally cannot obtain the discovery necessary to bring an antitrust claim, can get only single damages, and must usually pay fees and costs if they lose. ${ }^{46}$

\footnotetext{
44 See Elhauge, Defining Better Monopolization Standards, supra note 11, at 331-32.

${ }^{45}$ See Lars-Hendrik Röller, Exploitative Abuses 9-13 (European School of Management and Technology, Business Brief No. BB-107-002, 2007) (taking this position), available at http://www.esmt.org/fm/294/BB-107-002_Roeller_Expoitative_Abuses.pdf; $c f$. Emil Paulis, Article 82 EC and Exploitative Conduct, in European Competition Law Annual 2007 515, 518-19 (Claus-Dieter Ehlermann \& Mel Marquis eds., 2008) (arguing that this gap might explain why the EU has an excessive pricing claim but not advocating that excessive pricing claims be limited to cases where the dominant power was acquired illicitly).

${ }^{46}$ See Elhauge \& Geradin, supra note 42, at 43.
} 
Perhaps an EU court would conclude that such a disgorgement claim is implicitly precluded by the limits on the fines the European Commission can impose. ${ }^{47}$ However, U.S. limits on agency fines have not been interpreted to preclude disgorgement claims. Further, because excessive pricing is itself an infringement of Article 82, the Commission's authority to enter orders ending any infringement could be interpreted to include orders undoing the excessive prices by ordering disgorgement of the price excesses. ${ }^{48}$

This sort of approach to excessive pricing might also help address a current gap in EU merger law. In a recent case, the FTC sued to undo a merger four years after it occurred, on the ground that prices went up after the merger and thus showed the merger had in fact turned out to be anticompetitive, even if that had not been sufficiently clear to bring a challenge before the merger. ${ }^{49} \mathrm{EU}$ merger law does not seem to provide any authority to undo retroactively a properly notified merger that the Commission concluded should not be blocked when it occurred. However, if a merger creates a dominant position that leads to increased prices, it would seem the EC could bring an excessive pricing claim against the merged firm that, if coupled with seeking a break-up remedy for the excessive pricing, would effectively be the same as the FTC suit. Disgorgement of merger-created profits might also be a remedy that either the EU or U.S. agencies could pursue.

This might be a quite helpful doctrine. In particular, consider a case where it is a close question whether a merger is anticompetitive or procompetitive. In such close cases, regulators could allow the merger, figuring they could always reduce the costs of Type II errors after the fact by suing to undo, or disgorge profits from, a merger that turned out to actually be anticompetitive. The prospect of stronger post-merger remedies should, in short, make it optimal to be less aggressive in blocking mergers in the first place.

Lars-Hendrik Röller worries that such retroactive actions would increase Type I errors because it would create two opportunities for erroneous condemnation. ${ }^{50}$ However, he fails to consider the fact that the availability of retroactive remedies should make the agency less willing

\footnotetext{
${ }^{47}$ See Council Regulation (EC) 1/2003, art. 23(2), 2003 O.J. (L 1) 1, 17.

${ }^{48}$ See id. art. 7, 2003 O.J. (L 1) 1, 9.

${ }^{49}$ Although the Commission upheld the power to seek retroactive divestiture, it ultimately decided this was the unusual case where behavioral remedies were preferable to structural ones. See Evanston Nw. Healthcare Corp., FTC Docket No. 9315, Opinion of the Commission at 89 (2007), available at http://www.ftc.gov/os/adjpro/d9315/070806opinion.pdf.

${ }^{50}$ Röller, supra note 45 , at 10.
} 
to bring uncertain prospective cases. Indeed, if the enforcer is acting optimally, it should choose the retroactive approach over the prospective one only when doing so reduces the combination of expected overdeterrence and underdeterrence. Adding the option thus cannot worsen over- and underdeterrence unless the agency fails to use its power wisely.

\section{REMAINING QUALMS}

Still, I suspect that, for many, qualms may remain about allowing government officials in the United States or the EU to bring disgorgement claims. But I think the above suggests the deeper source of those qualms is not really that alternative remedies are better placed to optimally regulate conduct. Instead, the deeper qualms are that the government might abuse such a power rather than employ it optimally.

One deep-rooted concern is, I think, the fear that it simply gives government officials too much power to have them regularly bring actions for disgorgement of ill-gotten monopoly profits. This is a serious concern, and one would want to make sure the process for bringing such cases was not distorted by political bias. But this is hardly a concern unique to federal antitrust agencies. After all, U.S. antitrust law quite explicitly gives states the right to bring a parens patriae action on behalf of its residents. ${ }^{51}$ Likewise, the SEC routinely seeks disgorgement in its enforcement actions. It is hard to see why state antitrust enforcers or federal securities agencies should be deemed more reliable or less worrisome than federal antitrust agencies. Indeed, the former raise greater concerns, both because the state antitrust actions are for treble damages and because the SEC actions largely result in transfers from some innocent shareholders to other innocent shareholders.

One would also, in all public disgorgement cases, have the protection not only of a disinterested agency process, but also review by independent courts. This is, if anything, more protective of defendants than the process in a properly certified class action. Moreover, the alternative to having the government seek monetary equitable relief is generally for it to seek regulatory forms of equitable relief. Such regulatory relief raises similar concerns about political bias, while, in addition, raising concerns about heavy-handed government regulation whose costs are harder to ascertain and police because they are less salient and quantifiable.

Another concern might be that the prospect of making hundreds of millions of dollars through a disgorgement claim could make govern-

${ }^{51} 15$ U.S.C. $\$ 15 \mathrm{c}$. 
ment officials overzealous. This might be a particular concern in the cases where disgorgement is most useful as a remedy-namely, the cases where it is hard to calculate the harm to specific individuals but easier to calculate the illicit profits to disgorge-because those are the very cases where the disgorged funds are likely to go to the government. ${ }^{52}$ One would not want government officials pursuing dubious antitrust cases because the expected proceeds exceeded the litigation costs in a way that made such cases a profit center. On the other hand, meritorious injunctive suits are often politically undervalued because they result in no easily quantifiable benefit. Probably the best way to minimize distortion is to make sure that, when there is no practicable way of delivering disgorged profits to the victims, such disgorgement proceeds should go to the general treasury and not affect the budget of the agencies. Which, conveniently enough, is precisely what U.S. law provides. ${ }^{53}$

\section{CONCLUSION}

In short, the disfavored status of disgorgement as an antitrust remedy is somewhat puzzling. Like all remedies, it raises problems. But the alternative government remedies often are ineffective or raise even worse problems. Their regulatory nature often makes them inefficient or overburdensome, and narrowing their use to avoid these problems often makes them ineffectual or illusory. Disgorgement neatly avoids these problems by monetizing the obligation in a way that eliminates any need for government and judicial entanglement in ongoing business operations. It replaces intrusive command-and-control forms of regulation with less intrusive, and often more efficient, regulation via a price mechanism.

Indeed, one might wonder whether the question should not be asked in reverse. After all, the traditional standard for injunctive relief is not that damages should be pursued only when injunctive relief is inadequate; it is that injunctive relief should be granted only when damages cannot provide an adequate remedy. ${ }^{54}$ The best justification for this traditional standard is that damages require less judicial intrusion into the ongoing conduct of private parties. Because the government cannot obtain damages in a typical antitrust case, the closest it has to a claim for damages is a claim for disgorgement. The justification for the traditional standard thus suggests that the government should look first to bringing

\footnotetext{
52 See, e.g., FTC v. Febre, 128 F.3d 530, 533, 537 (7th Cir. 1997); FTC v. Gem Merch. Corp., 87 F.3d 466, 470 (11th Cir. 1996).

${ }^{53}$ See 31 U.S.C. § 1341; 31 U.S.C. § 3302; AT\&T v. United States, 177 F.3d 1368, 1373 (Fed. Cir. 1999).

${ }^{54}$ See, e.g., Bowen v. Massachusetts, 487 U.S. 879, 925 (1988).
} 
a disgorgement claim and bring a claim for regulatory injunctive relief like divestiture or behavioral orders only when disgorgement would be inadequate. This seems opposite to the current U.S. government agency approach of looking mainly to regulatory forms of injunctive relief and disfavoring monetary forms.

One might answer that the government should not pursue any equitable remedies-monetary or regulatory-unless damage actions by private parties have been shown to be inadequate. But that would be a revolution in antitrust enforcement-among other things, it would suggest that generally the government should not challenge any mergers because private parties could always pursue damage actions after the fact against any mergers that actually raise prices. In any event, even if that were the right standard, the fact is that private damage actions are often inadequate, especially given the bars to suits by indirect purchasers who suffer most of the harm and the increasing obstacles to class actions and monopolization cases.

Perhaps a more serious concern is that disgorgement might be too modest a remedy. To fully deter misconduct, one would want the penalty to equal the total harm created by the conduct divided by the ex ante probability of detection and successful adjudication. Disgorgement of illicit profits does not cover the total harm because it excludes the harm created by either the deadweight loss or the umbrella effect on rival prices ${ }^{55}$ Disgorgement also fails to give any adjustment for the odds that misconduct might not be detected or successfully punished. Fully redressing cases where private damage suits and alternative government remedies are inadequate may thus require the authority to impose fines adequate to achieve optimal deterrence. ${ }^{56}$ But such a broad fining authority does not exist under the current statutory scheme, while disgorgement authority does, and pursuing disgorgement claims can at least reduce some of the shortfall in deterrence, as well as achieve the goal of depriving the antitrust wrongdoer of its illicit loot.

\footnotetext{
${ }^{55}$ Disgorgement can, on the other hand, avoid the problem that damages usually do not compensate for prejudgment interest by measuring disgorged profits to include the normal rate of return the wrongdoer earned (or could have earned) on illicit profits. I would not recommend having disgorged profits include actual returns on illicit profits, because that would treat efficient investments of illicitly gained funds worse than inefficient investments of such funds, thus discouraging efficient investment decisions that are unrelated to the wrongdoing.

${ }^{56}$ Concerns that disgorgement might lead to excessive penalties over and above private treble damages would be avoided if, as I have suggested above, the funds are held in escrow pending private actions to avoid exceeding triple the total harm.
} 
